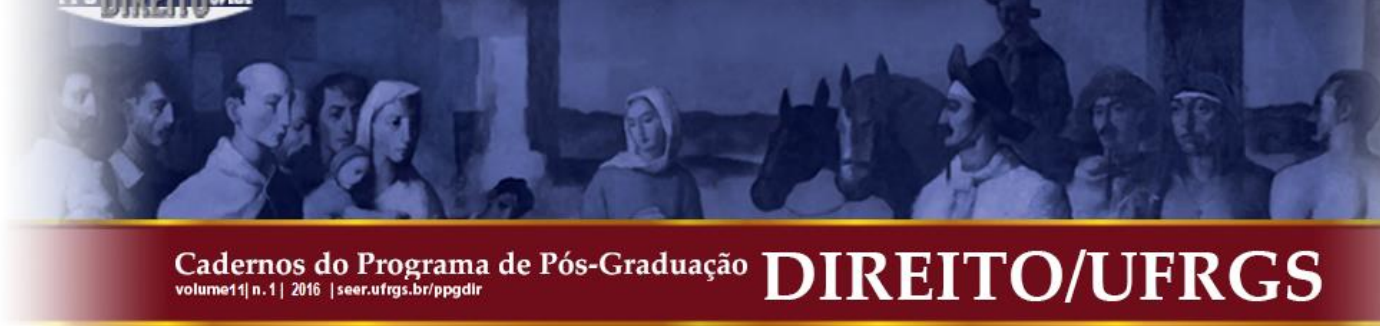

\title{
TUTELA JURISDICIONAL: OS PRECEDENTES JUDICIAIS E (AS VICISSITUDES DE) SUA APLICAÇÃO NO MODELO JUDICIAL BRASILEIRO
}

\author{
JUDICIAL PROTECTION: THE JUDICIAL PRECEDENTS AND (THE FLAWS OF) THEIR
}

APPLICATION IN BRAZILIAN JUDICIAL SYSTEM

André Nogueira*

\begin{abstract}
RESUMO: O estudo aborda tema concernente à necessidade de se repensar a prestação da tutela jurisdicional no Brasil, especialmente, em decorrência do fortalecimento dos precedentes judiciais no sistema processual brasileiro e sua aproximação com o modelo jurídico da família do common law. Essa nova postura exige observância da ratio decidendi para aplicação dos precedentes, não somente a consideração de meras súmulas e verbetes, como percebemos através da pesquisa elaborada, de modo a proporcionar uma tutela realmente efetiva e capaz de assegurar segurança jurídica.
\end{abstract}

PALAVRAS-CHAVE: Precedentes. Common Law. Tutela jurisdicional.

SUMÁRIO: Introdução. 1 Perspectiva Constitucional da Tutela Jurisdicional. 2 Os Precedentes Judiciais no Sistema Processual Civil Brasileiro: um common law à moda da casa? Conclusão. Referências.

\section{INTRODUÇÃO}

É clarividente que o processo civil pátrio tem suportado uma vasta gama de modificações especialmente tendentes à busca da prestação de uma tutela jurisdicional mais efetiva e célere, notadamente, após a Edição da Emenda Constitucional no 45/2004. Aliás, podemos perceber nesse estudo que o processo civil sempre fora tangenciado em nossos textos constitucionais, muito embora, tal fenômeno tenha ganhado relevante espaço na Constituição da República de 1988.

A par dessa característica de constitucionalização do processo, muito bem trabalhada pela doutrina e jurisprudência pátria, tem se verificado que o processo civil vem sendo amplamente transformado na esfera infraconstitucional, obtendo relevo neste trabalho o tema afeto ao fortalecimento dos precedentes judiciais como ferramenta de garantia da segurança

\footnotetext{
* Doutorando e mestre em Sistema Constitucional de Garantia dos Direito Humanos no Instituto Toledo de Ensino (ITE), Bauru, São Paulo. Professor e Coordenador do Curso de Direito do Instituto Toledo de Ensino (ITE), Botucatu, São Paulo. Advogado e Presidente da $25^{\mathrm{a}}$ subseção da Ordem dos Advogados de São Paulo (OAB-SP).
} 


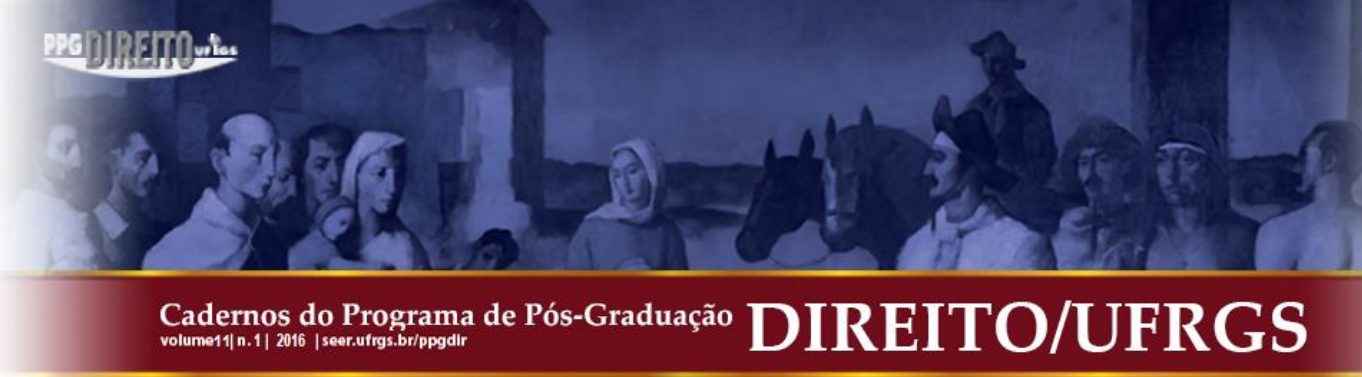

jurídica e de aceleramento na prestação de tutela, o que também fora lembrado na redação do novo Código de Processo Civil.

Referido modelo de direito jurisprudencial, tradicionalmente manejado em sistemas jurídicos da família do common law, realmente, é bastante importante na consecução de tais objetos, não podendo, contudo, nos esquecermos que os precedentes nessa tradição jurídica transmitem a formação de uma jurisprudência construída pela razão de decidir (ratio decidendi) e não em meros enunciados, verbetes ou súmulas editadas por tribunais.

Hodiernamente, em nosso ordenamento jurídico, inúmeras são as ferramentas processuais que incrementam a força dos precedentes, entrementes, temos notado que o modelo judicial brasileiro tem implicado esse notável instituto de forma absolutamente distorcida, criando uma espécie de common law à moda da casa, o que gera nefastos efeitos aos primados da efetividade da prestação jurisdicional, merecendo, pois, melhor reflexão, tal como o objeto do presente trabalho.

\section{PERSPECTIVA CONSTITUCIONAL DA TUTELA JURISDICIONAL}

$\mathrm{Na}$ oportunidade em que nos deparamos com um trabalho que almeja abordar temas conexos à uma teoria da Constituição, tal como proposto no presente, é salutar que tornemos claro que as Constituições brasileiras sempre se mostraram tendenciosas a tangenciar temas relacionados ao processo em seus mais diversos aspectos.

Diga-se de passagem, não poderia ser diferente, visto que, cuidando-se o Órgão Judiciário de uma das pilastras de nosso Estado, o Texto Maior não poderia se furtar dessa parcela fundante de extremo relevo na mantença de toda estrutural social.

Neste diapasão, podemos, a título meramente exemplificativo, citar diversas passagens em textos constitucionais que se referiram ao tema, sem qualquer pretensão de esgotá-las, tal como a garantia do tribunal do júri, na Constituição do Império de 1824 ou, ainda, a estrutura organizacional do Judiciário, no Art. 55, da primeira Constituição Republicana pátria, datada de 1891.

Podemos lembrar, outrossim, do mandado de segurança, imprescindível ação constitucional típica ou remédio constitucional, previsto no Art. 113, item 33, da Constituição de 1934, cuja qual também enfatizou que “a lei assegurará aos acusados ampla defesa, com 


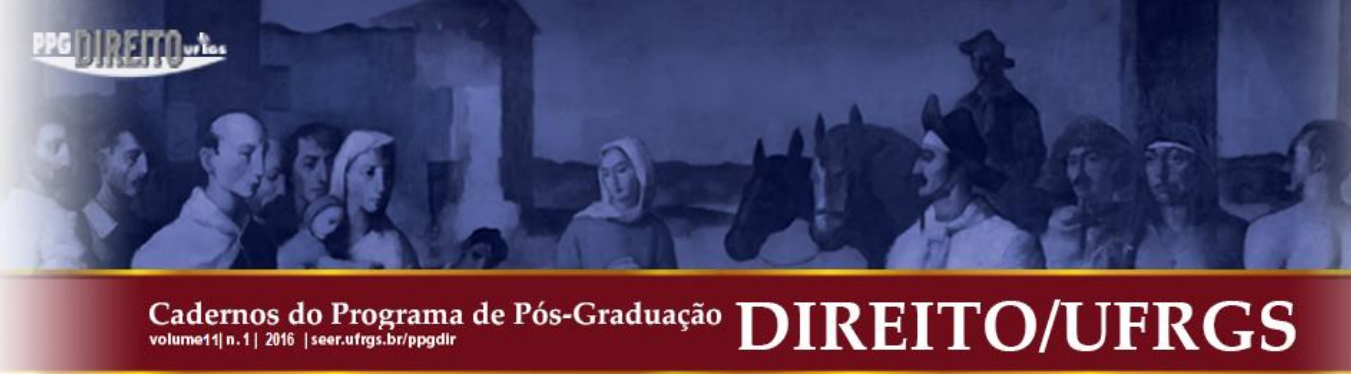

os meios e recursos essenciais a esta", no item 24 do mesmo dispositivo constitucional aludido.

Quiçá, poderíamos lembrar da Constituição Democrática de 1946, a qual, em seu Art. 114, ao cuidar das Garantias e Direitos Individuais, $m$ seu $\S 25$, determinou a necessidade de observância do devido processo legal e da plena defesa, além de reconhecer a necessidade de ferramentas que viabilizassem o dever estatal de concessão de assistência judiciária gratuita.

Enfim, poder-se-ia colacionar uma vastidão de normas constitucionais que efetivamente versaram acerca de temas tipicamente processuais, nas mais diversas Constituições editadas no Brasil (até a promulgada em 1988, são oito, se considerarmos a de 1969, como texto constitucional apartado daquela editada em 1967, o que, por não ser o cerne do presente estudo, não será aqui discutido), entrementes, a fim de não nos desviar do cerne deste trabalho, muito menos torna-lo enfadonho, citamos somente alguns exemplos para enfatizar a importância da matéria "prestação jurisdicional" nos textos magnos.

Aliás, cumpre destacarmos que a cada dia que passa essa tendência de se levar o processo à Constituição e a Constituição ao processo tem se alargado, sendo repisadas as expressões como "constitucionalização do processo", ensejadoras, até mesmo, de novos ramos didáticos do direito, bastando nos lembra do Direito Processual Constitucional.

Nessa esteira de silogismo poderíamos suscitar o novo Código de Processo Civil (Lei $\mathrm{n}^{\mathrm{o}}$ 13.105/2015), o qual dedicou espaço próprio reservado ao tema, abordando-o, de forma específica e bastante evidenciada, de imediato, no Título Único (Das Normas Fundamentais e da Aplicação das Normas Processuais), do Livro I, de sua Parte Geral, Art. $1^{\circ 1}$, cuidou de demonstrar o liame da nova legislação processual com a Constituição da República (insta salientar que o novel Código de Processo Civil, no Brasil, será o primeiro código, dessa natureza, que teve sua tramitação iniciada e concluída com a edição de seu texto normativo em período integralmente democrático).

Por se falar em Constituição, nenhuma Carta fora tão pródiga em cuidar de princípios e garantias relacionadas ao processo, afora outros temas concernentes à estrutura do Judiciário, ações constitucionais, atribuição de competências, cabimento e requisitos para admissibilidade recursal, dentre tantos outros pontos que poderiam ser aqui ventilados, como

\footnotetext{
1“Art. 1": O processo civil será ordenado, disciplinado e interpretado conforme os valores e as normas fundamentais estabelecidos na Constituição da República Federativa do Brasil, observando-se as disposições deste Código."
} 
a Constituição Federal de 1988; sua prolixidade, característica de nosso Texto Constitucional, fez com que, a par da abordagem de diversos outros ramos do Direito (expressão que nos valemos para fins puramente didáticos), inúmeros outros elementos do processo civil fossem lembrados pelo constituinte, originário ou derivado (v.g., a Emenda Constitucional $n^{\circ}$ 45/04, que para muitos fora denominada Reforma do Judiciário ou Pacto Republicano do Judiciário).

Esse vasto cabedal normativo constitucional referente ao processo civil, por evidente, tem alguns propósitos, notadamente, estabelecer um processo que assegure paz e harmonia social, além de que seja voltado para o povo, à sociedade carecedora da prestação jurisdicional como ferramenta de consagração do sentimento de justiça, indubitável para mantença da estabilidade de um Estado de Direito.

Além disso, pretendendo nosso Estado de Direito ser substancialmente democrático, inarredável que o processo civil preste-se como instrumento de fortalecimento da democracia, conspirando para a consecução dos fins desse sistema, de tal modo a favorecer a construção de uma sociedade que tenha assegurada liberdade, propriedade, igualdade material, segurança jurídica e fraternidade, sob pena de instituirmos um processo alheio à finalidade do Estado Democrático proposto desde o Preâmbulo da Constituição de 1988, enaltecendo-se a redação dos Artigos $1^{\circ}$ e $3^{\circ}$, da Lei Maior, que versam sobre os fundamentos e objetivos de nosso Estado.

Nessa mesma toada, de iniludível conhecimento que, através do tempo, a sociedade se transforma, buscando amoldar-se aos contornos que visam a consagração de um bem-comum, mediante mecanismos das mais variadas naturezas e atuantes nas mais diversificadas searas dessa complexa estrutural organizacional.

Por não se tratar do objeto de estudo não iremos nos aprofundar na concepção de "bemcomum", entrementes, é cediço que a edificação desse primado passa pela atuação do Poder Estatal em inúmeras sendas, dentre as quais a que aqui nos interessa, a atuação jurisdicional. A propósito, é bastante clássica a lição de que através do processo a sociedade objetiva a pacificação do grupo social com efetivação da justiça.

Não menos reiterada é a afirmação chiovendiana de que o escopo principal do processo é prestar-se como ferramenta para construção desse ideal social de pacificação e de entrega da tutela jurisdicional àquele que vê-se lesado ou ameaçado de lesão, de tal sorte que "o processo deve entregar aquilo e exatamente aquilo que ele tenha direito de conseguir" 


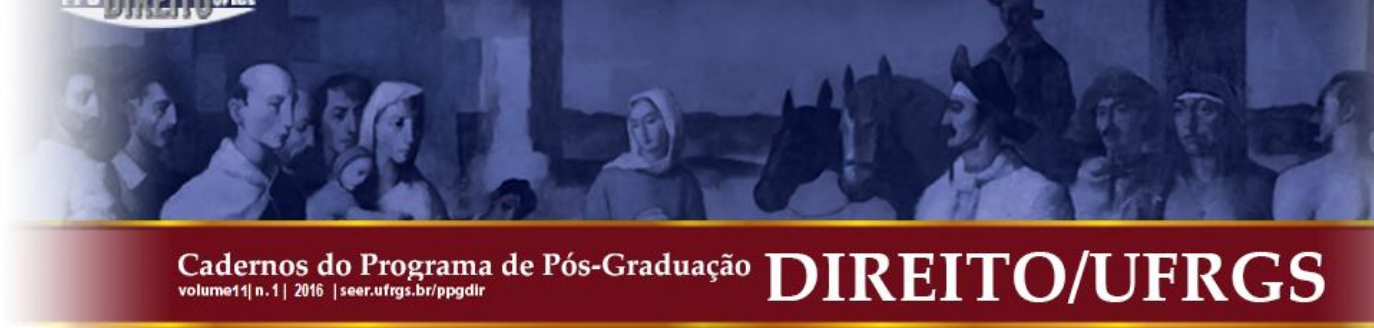

(CHIOVENDA, 2009, p. 67), o que mais tarde convencionou-se denominar de instrumentalidade do processo.

Não obstante o evidente esforço doutrinário e legislativo na obtenção de uma tutela jurisdicional mais célere e efetiva - basta, para tanto, observarmos as profundas mudanças havidas no processo civil, notadamente, após a edição da Emenda Constitucional $n^{\circ}$ 45/04, alhures lembrada e que trouxe em seu bojo o princípio da duração razoável do processo, esculpido no acrescido inciso LXXVIII, do Art. $5^{\circ}$, até os dias atuais onde se aproxima a edição do novo Código de Processo Civil -, na prática judiciária, ainda podemos denotar uma série de mazelas que comprometem a tão almejada efetividade esperada pela Constituição em seu texto e tão relevante para fortalecimento do processo democrático brasileiro.

Ademais isso, sendo o Órgão Judiciário um dos pilares de sustentação da estrutural estatal e, por conseguinte, da busca pela construção do bem-comum, pertinente se faz refletirmos acerca do caminho que nossa prestação jurisdicional tem tomado no tocante à pacificação do seio social com consagração da justiça ${ }^{2}$, especialmente porque, com a promulgação da atual Constituição da República, houve um indisfarçável acréscimo na demanda processual perante o Judiciário para consagração de direitos de uma vasta camada da sociedade, até então, alijada dessa ferramenta.

A luta pela satisfação dos direitos mediante a efetiva prestação jurisdicional encontra-se intimamente relacionada com a questão do constitucionalismo moderno, o que, por muitos, tem sido abordado como neoconstitucionalismo, o qual tem voltado seus esforçados à tentativa de consagração das normas constitucionais e à concepção de força ativa da Constituição, o que não seria diferente no concernente ao processo civil e sua duração razoável e efetividade.

Tem-se notado com alguma facilidade que, sob influência decisiva desse neoconstitucionalismo, se almeja construir novas bases para o processo civil brasileiro, de modo a assegurar, pela substancialização de princípios processuais constitucionais, uma prestação jurisdicional que, concretamente - não de forma meramente formal ou procedimental -, corresponda à pacificação e harmonia social, como consagrado na Constituição Federal.

\footnotetext{
2 “A pacificação é o escopo magno da jurisdição e, por consequência, de todo sistema processual(...). É um escopo social, uma vez que se relaciona com o resultado do exercício da jurisdição perante a sociedade e sobre a vida gregária dos seus membros e felicidade pessoal de cada um". DINAMARCO, Cândido Rangel. $A$ instrumentalidade do processo. 12. ed. São Paulo: Malheiros, 2005, p. 24
} 


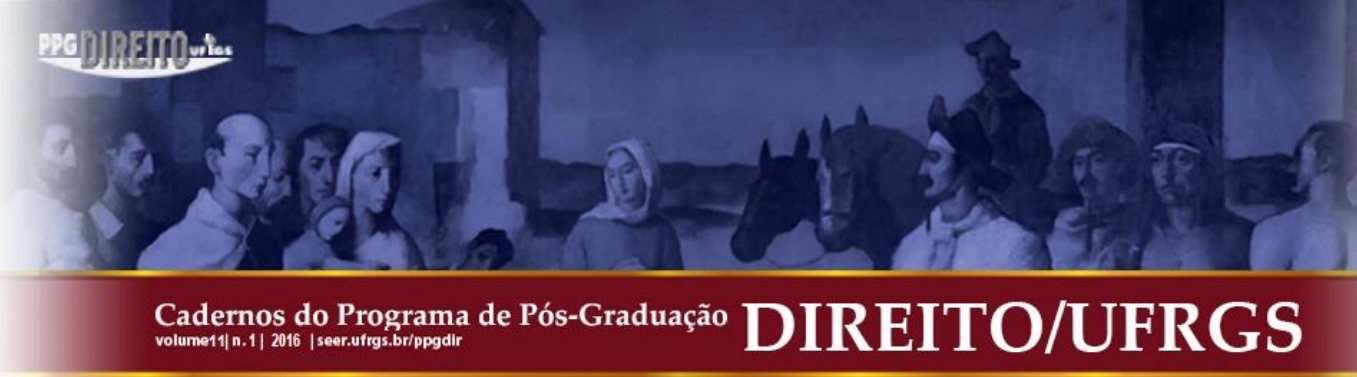

Tal transformação na forma como se pensa o processo civil também merece ser carregada para o modo como se atua no processo, em especial, no que diz respeito ao rompimento de dogmas e paradigmas construídos em outra realidade socioeconômica e cultural, superação de formalismos exacerbados e do modelo como se apreciam os feitos levados ao Judiciário, quer-se dizer, é imprescindível que o processo seja visto como instrumento, meio de consecução de entrega da tutela e não como fim em si mesmo, sendo igualmente inafastável a necessidade de repensarmos a influência dos precedentes judicias no tocante à resolução dos litígios levados à apreciação do Judiciário.

A primeira assertiva é antiga, no entanto, ainda assim, muito distante de ser efetivamente observada. Com relação à segunda, não há como negar que os conflitos sociais com os quais nos deparamos nos dias de hoje não correspondem àqueles perceptíveis há décadas atrás, de tal sorte que a atividade jurisdicional, necessariamente, deve perceber tal contexto e transformar-se, a fim de que esteja apto a assegurar a convivência social e eliminar os litígios que, naturalmente, sempre existiram e continuaram existir.

Os litígios estão, a cada dia mais, chegando às portas do Judiciário, talvez, graças à uma incansável tentativa de acesso à justiça, no entanto, essa massificação de demandas, a par de inúmeras outras dificuldades, tem implicado num ambiente de notória instabilidade institucional no Judiciário pátrio, o que se mostra temerário.

Como aduzimos, o excesso de demandas tem gerado incontáveis problemas ao Judiciário que, despreparado e sem estrutura para receber esse incremento processual, passa, em nome de um acesso puramente formal à justiça, receber tais pleitos sem a menor condição de entregar a resposta jurisdicional almejada pela sociedade.

Dentre tantas outras circunstâncias gravosas geradas, iremos nos concentrar naquela que concerne à gritante insegurança jurídica e a inarredável necessidade de construção novos paradigmas na Ciência Processual de respeito e de construção/formação dos precedentes judiciais, como ferramenta de efetivação do acesso substancial à ordem jurídica justa, de tal forma que esse rompimento com o modelo clássico proporcione, verdadeiramente, um cenário de estabilidade institucional, igualmente entre aqueles que se valem do serviço jurisdicional e, assim, consiga cumprir com os primados constitucionais que depositam no processo civil a expectativa de fortalecimento/amadurecimento do processo democrático brasileiro. 


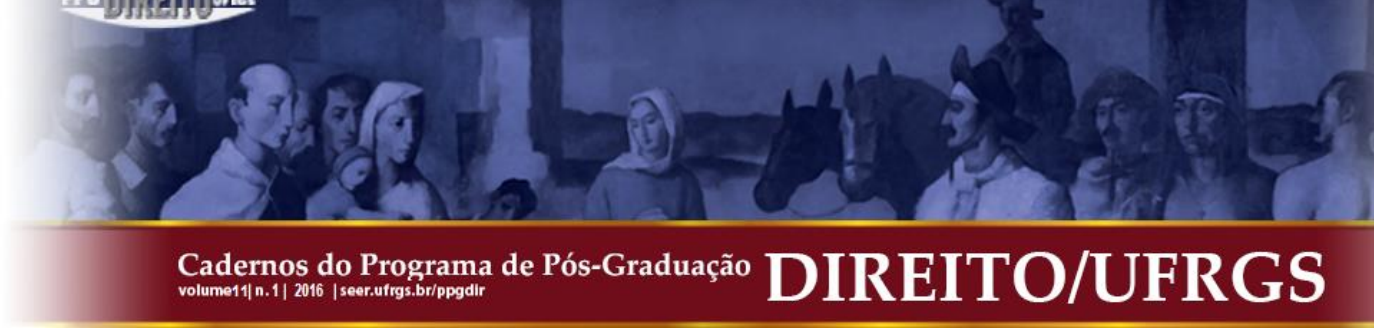

\section{OS PRECEDENTES JUDICIAIS NO SISTEMA PROCESSUAL CIVIL BRASILEIRO: UM COMMON LAW À MODA DA CASA?}

É certo que qualquer Estado Democrático de Direito que se preze necessita observar a obediência à segurança jurídica, indispensável como alicerce desse modelo de organização estatal, tanto que fora positivada como direito fundamental no Art. $5^{\circ}$, caput da Constituição Federal de 1988 e com reflexo em diversos outros dispositivos constitucionais como nos incisos XXXVI e XL, do referido Art. $5^{\circ}$.

Somente para que tenhamos uma breve definição desse instituto jurídico intimamente relacionado às estruturas do Estado de Direito, nos aproveitamos da lição de Celso Antônio Bandeira de Mello (2001, p. 93-94), que pondera:

O Direito propõe-se a ensejar uma certa estabilidade, um mínimo de certeza na regência da vida social. Daí o chamado princípio da 'segurança jurídica', o qual, bem por isso, se não é o mais importante dentre todos os princípios gerais de Direito, é, indiscutivelmente, um dos mais importantes dentre eles. Os institutos da prescrição, da decadência, da preclusão (na esfera processual), da usucapião, da irretroatividade da lei, do direito adquirido, são expressões concretas que bem revelam esta profunda aspiração à estabilidade, à segurança, conatural do Direito.

(...) Esta 'segurança jurídica' coincide com uma das mais profundas aspirações do homem: a da segurança em si mesma, a da certeza possível em relação ao que o cerca, sendo esta uma busca permanente do ser humano. É a insopitável necessidade de poder assentar-se sobre algo reconhecido como estável, ou relativamente estável o que permite vislumbrar com alguma previsibilidade o futuro; é ela, pois, que enseja projetar e iniciar, consequentemente - e não aleatoriamente, ao mero sabor do acaso-, comportamentos cujos frutos são esperáveis a médio e longo prazo. Dita previsibilidade é, portanto, o que condiciona a ação humana. Esta é a normalidade das coisas.

Bem por isto, o Direito, conquanto seja, como tudo o mais, uma consequente mutação, para ajustar-se a novas realidades e para melhor satisfazer interesses públicos, manifesta e sempre manifestou, em épocas de normalidade, um compreensível empenho em efetuar suas inovações causando o menor trauma possível, a menor comoção, à relações jurídicas passadas que se perlongaram no tempo ou que dependem da superveniência de eventos futuros previstos.

É evidente que num cenário mundial de constante evolução e de profundas transformações e instabilidades sociais, o prestígio pela segurança jurídica por parte do Estado seja relevante para determinar o direcionamento de investimentos privados e públicos, nacionais e internacionais, produtivo ou especulativo, os quais produzem intromissões diretas e indiretas na vida dos membros de uma sociedade.

Nessa toada de busca de estabilidade das relações sociais e jurídicas é iniludível que os posicionamentos adotados pelo Judiciário ganham notoriedade e ultrapassam os limites da lide intersubjetiva, conforme concepção tradicionalmente adotada pela Escola Clássica do 


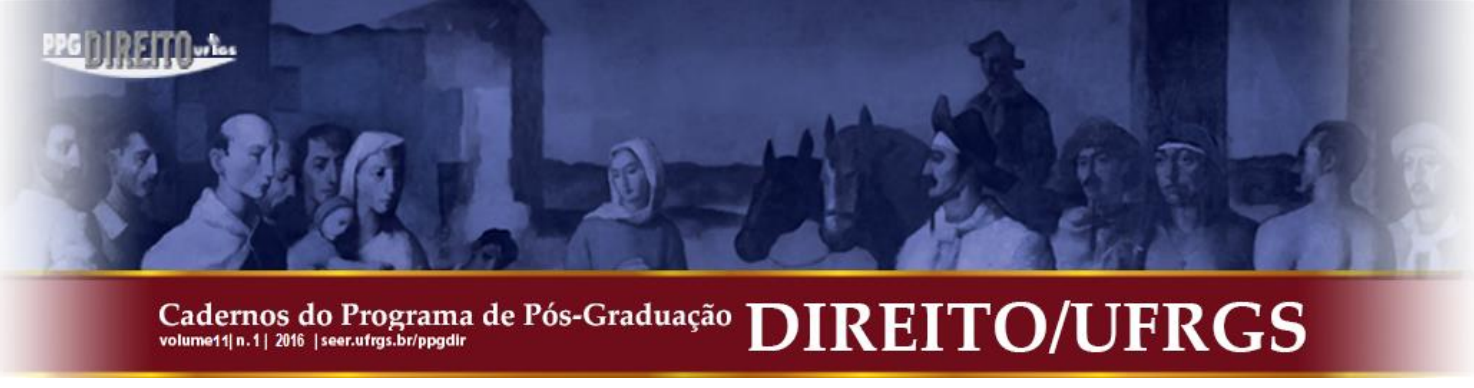

Direito Processual e que emoldurou nosso sistema processual civil de 1973, tal como, exemplificativamente, se observa do disposto no art. 472, do Código de Processo Civil, ao tratar dos limites subjetivos da coisa julgada.

Neste ponto, Carlos Alberto Álvaro de Oliveira (2009, p. 78-83), afirma:

(...) servindo o processo para realização do direito material, não pode a lei processual estabelecer regulação que, por motivos meramente processuais, ponha em perigo, com risco até de eliminá-la, a igualdade jurídica assegurada pela norma material. Tais considerações afastam a possibilidade de se conceder espaço no processo a um poder incondicional do órgão julgador, como se este pudesse ser o 'senhor do processo (Herr des Verfahrens)'....atitude dessa ordem poderia conduzir a desigual realização do direito material.

(...) mostra-se importante atentar ainda para a aplicação do direito: não só a norma jurídica deve ser formulada de maneira clara, acessível e previsível, mas também previsível deve ser o resultado do litígio, sem causar estranheza no meio social onde deve atuar. As soluções exóticas, com clara afronta ao sistema, além de surpreender, deslegitimam o Poder Judiciário perante a sociedade.

(...) o valor da paz social insta a que se tente eliminar com presteza o conflito, mediante o emprego de meios reconhecidamente idôneos. Já se acentuara, aliás, no início do século XX, essa vocação do processo, considerado um mal social (expressão de Frederico, o Grande), um fenômeno doentio, a ser suprimido da maneira mais rápida possível, mormente porque sua frequente repetição representa autêntico perigo para a sociedade.

Interessantes são as palavras de Roberto Rosas e Paulo Cezar Aragão (1998, p. 27-28), segundo os quais,

O homem do povo não concebe duas decisões antagônicas resolvendo a mesma tese, o mesmo princípio, o mesmo fato....que importa a lei ser igual para todos, se for aplicada de modo diferente a casos análogos?....se a lei é uma, não admitirá duas teses consequentes. $\mathrm{O}$ fato de uniformizar-se a jurisprudência não significa estiolar a interpretação do Direito e da lei.

Outrossim, nos aproveitamos das palavras de Marcelo Alves Dias de Souza (2013, p. 305-306), apontando que:

Nada mais justo que casos semelhantes sejam resolvidos de modo semelhante; ao revés, nada mais injusto que esses casos (semelhantes) sejam decididos, arbitrariamente, de modo diversos. Aí está o importante papel da doutrina do stare decisis: ela requer, pelos seus próprios termos e por sua própria concepção, decisões semelhantes para casos semelhantes, de sorte a evitar qualquer desigualdade arbitrária em prejuízo do jurisdicionado e da própria administração da justiça.

Nota-se, pois, que a segurança jurídica exige que as decisões judiciais acerca de teses análogas caminhem no mesmo em cima do mesmo trilho, direcionadas no mesmo sentido, proporcionando o mínimo de previsibilidade e calculabilidade de riscos àqueles que buscam a tutela jurisdicional do Estado, de maneira a impedir os perniciosos efeitos decorrentes de 


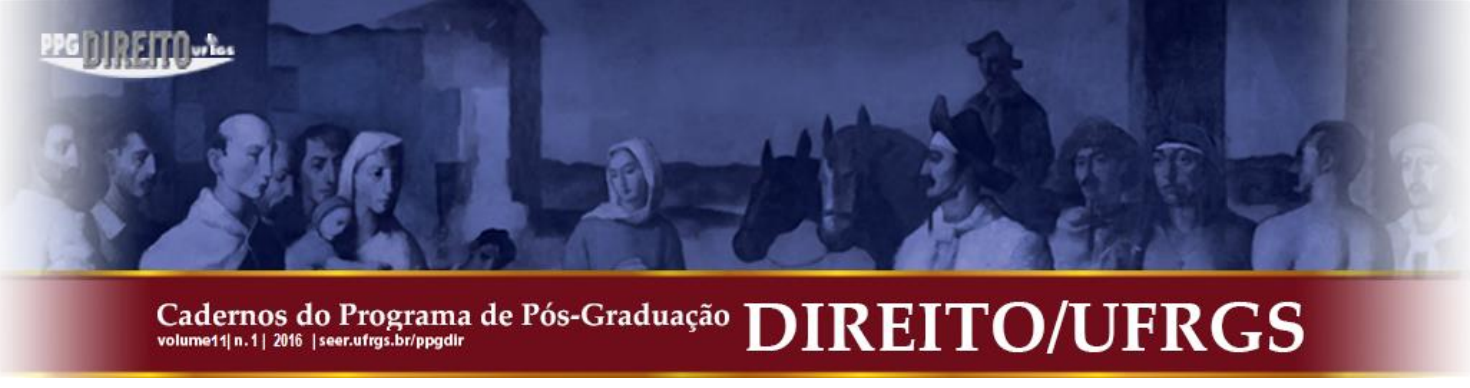

instabilidades ou satisfações pessoais dos magistrados escorados no ultrapassado espeque de julgamento livre conforme sua própria consciência, tornando o processo uma verdadeira loteria ou jogo de azar.

Nada obstante, em virtude do exacerbado número de feitos em trâmite perante nosso Judiciário, fruto de uma nova consciência jurídica da população brasileira e da viabilização do acesso material ao Judiciário, como outrora já ventilado, tem-se notado uma busca quase insana pelo aceleramento na prestação da tutela jurisdicional.

Veja bem, também concordamos com a necessidade inegável de que a tutela jurisdicional deve ser entregue de forma célere, até mesmo como obediência ao preceito constitucional da duração razoável do processo, entretanto, para nos valemos do jargão futebolístico, rapidez não pode ser confundida com pressa, e é assim que estamos notando o tema relacionado à observância dos precedentes judiciais no Brasil.

Acrescente-se a isso, que somos entusiastas da cultura do fortalecimento do precedente judicial como forma de buscar maior uniformidade e estabilidade jurisprudencial, o que certamente desemboca na efetividade da prestação da tutela, na segurança jurídica e na igualdade material daqueles indivíduos que, em situações análogas, terão suas demandas decididas de forma isonômica pelo Órgão Judiciário brasileiro, independentemente de onde resida ou onde seja a competência para processamento e ajuizamento dessas demandas. Seguindo esclarecedor texto de Gustavo Santana Nogueira (2013, p. 56-62), podemos afirmar que:

Em que pese a clareza da lei, a questão não é pacífica, o que obviamente causa uma enorme insegurança jurídica... Essa comparação (entre casos semelhantes e com julgamentos distintos), conquanto comum e regularmente feita pela análise de elementos dos julgados e evidentemente fraca e perigosa porque induz a erro o cidadão, que pode vir a pensar que os julgamentos no Judiciário, na melhor das hipóteses, são tão aleatórios quanto o sorteio dos números premiados de uma loteria. Não há análise séria de respeito ou desrespeito aos precedentes.[...] É um princípio básico da administração da justiça de que casos semelhantes devem receber a mesma decisão.

Ocorre que, pautado em casuísmos e na expectativa ensandecida de reduzir o número de feitos em trâmite perante nosso Judiciário ou proporcionar uma celeridade enganosa, o fortalecimento dos precedentes judiciais em nosso sistema processual tem se mostrado como uma verdadeira falácia, como passaremos a asseverar a seguir, ressaltando, mais uma vez, que somos absolutamente favoráveis à observância dos precedentes, no entanto, a forma como tal 


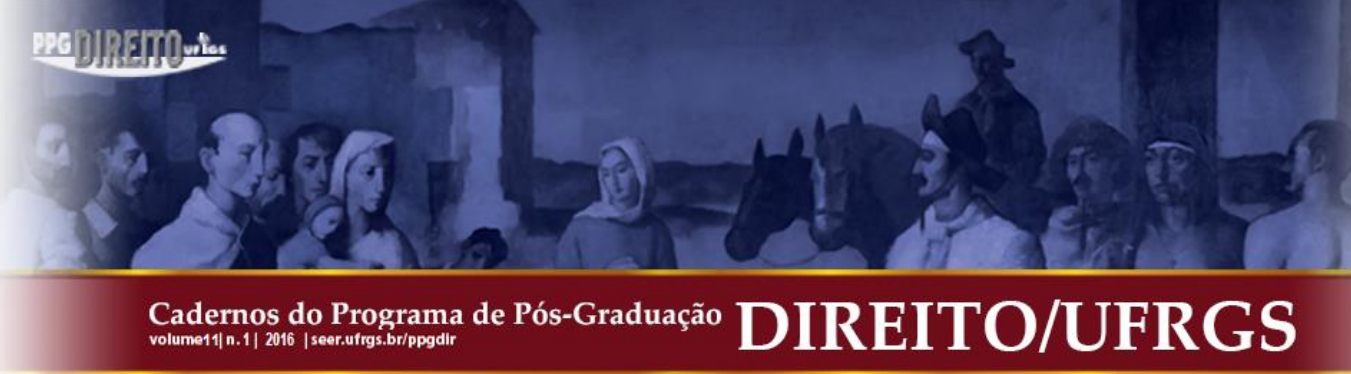

cultura vem sendo empurrada a fórceps na prática judiciária brasileira é digna da mais alta repulsa e evidencia o equívoco do sistema que se quer adotar.

Primeiramente, vale trazer à lume que não temos a cultura judiciária de obedecer precedentes, como bem lembra Luiz Guilherme Marinoni (2012, p. 564), que enfrentando o tema, bem enfatiza:

As decisões do Superior Tribunal de Justiça não são respeitadas no âmbito interno da Corte. As Turmas não guardam respeito pelas decisões das Seções e, o que é pior, entendem-se livres para decidir casos iguais de forma desigual. Resultado disso, como não poderia ser diferente, é o completo descaso dos juízes de primeiro grau de jurisdição e dos Tribunais Estaduais e Regionais Federais em relação às decisões tomadas pelo Superior Tribunal de Justiça. Isso configura um atentado contra a essência do direito e contra a efetividade do sistema jurídico.

Ou, noutra obra de mesma natureza, o processualista reforça que:

a segurança jurídica apenas pode ser garantida frisando-se a igualdade perante decisões judiciais, e, assim, estabelecendo-se o dever judicial de respeito aos precedentes.... Embora deva ser no mínimo indesejável, para um Estado Democrático, dar decisões desiguais a casos iguais, estranhamente não há qualquer reação a essa situação na doutrina ou na praxe brasileiras. (MARINONI, 2010, p. 100-101).

Não é de nossa formação a cultura de atribuir força a precedentes, sendo claro que desde os bancos da faculdade somos acostumados a tratar a jurisprudência através de um viés puramente secundário na formação do Direito, o que, por si só, merece ser alvo de melhor reflexão (e certamente não iremos incutir essa nova perspectiva da tutela jurisdicional através de alterações legislativas que empurram a observância de precedentes sem menor preocupação com critérios técnicos, como vem acontecendo em nosso processo civil).

Percebe-se o equívoco na edição incontrolável de textos legais ou, até mesmo, de verbetes judiciais sem qualquer diligência no sentido de fazer com que tais estipulações não sejam indevidamente aplicadas e distorcidas na prática forense, inclusive, muitas vezes, tais súmulas acabam prestando-se espeque para ausência de fundamentação das decisões desprezando um dos mais comezinhos princípios do direito processual, o da motivação, estatuído pelo art. 93, inciso IX, da Constituição Federal. Paralelamente ao apontado, podemos evidenciar a lição de Rodolfo de Camargo Mancuso (2010, p. 48-112), que aduz:

(...) o Estado é convocado a intervir nos conflitos intersubjetivos e nos metaindividuais, mas o que se verifica é que o instrumento de que se vale - a massiva emissão de normas repressivas - não é acompanhada de programas e estratégias de médio e longo prazo (a chamada telocracia); como resultado, a norma, 


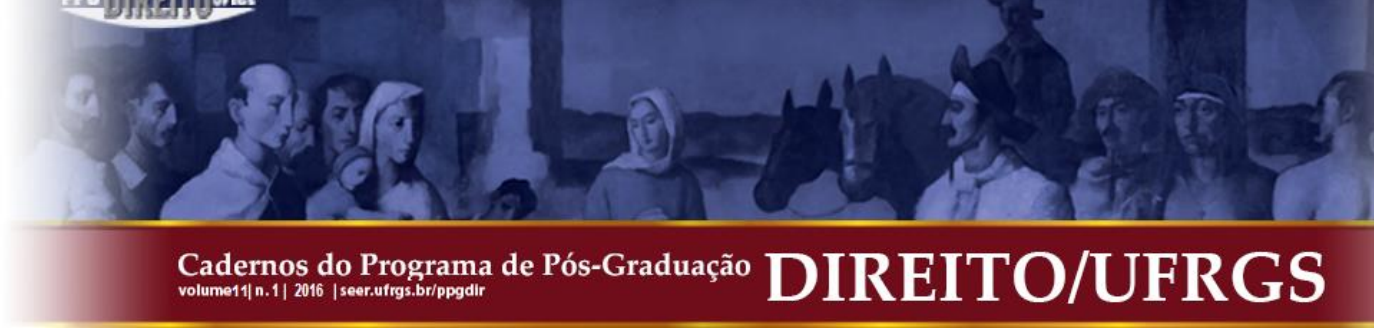

isolada, mostra-se impotente, tanto para prevenir a formação do conflito como para resolvê-lo

(...) Com isso tudo se vai superdimensionando a função judicial em termos quantitativos, e não qualitativos, sem um paralelo investimento na devida mudança de mentalidade de magistrados, sobretudo dos iniciantes, por modo a conscientizálos de que receberam parcela de poder, não pro domo sua, mas para empregarem-na em prol de uma ordem jurídica justa, em contemplação do jurisdicionado, o credo de uma resposta de qualidade: justa, jurídica, econômica, tempestiva e razoavelmente previsível.

A recente edição de um emaranhado de leis e a já usual edição de súmulas (persuasivas ou vinculantes) vem se apresentando como substrato de sustentação para o oferecimento de celeridade e aumento na produção jurisdicional, entrementes, deixa transparecer o gritante equívoco de nosso Judiciário que distorce institutos da common law que seriam tão relevantes para que, de fato, conseguíssemos um incremento em nossa prestação de tutela.

Temos visto institutos como as súmulas vinculantes, a repercussão geral no recurso extraordinário, o julgamento de casos repetitivos através da eleição equivocada de paradigmas, as negativas de seguimento aos recursos por conta de súmulas ou jurisprudência dominante, as súmulas impeditivas de recursos, o julgamento monocrático de recursos em razão de súmulas relacionadas à matéria recorrida, as sentenças liminares, todos voltados ao fortalecimento da manifestação reiterada de julgamentos acerca de determinados temas.

Toda essa vasta gama de alterações processuais, por evidente, nos aproxima da família e da tradição jurídica do common law, adotando uma espécie peculiar, sui generis, onde os fundamentos desses dois sistemas se intercalam e interagem na busca de objetivos comuns, com o que não discordamos, do contrário, nos mostramos absolutamente favoráveis em nome da segurança jurídica, da isonomia e da previsibilidade de resultados advindos da busca pela tutela prestada pelo Órgão Jurisdicional ${ }^{3}$.

\footnotetext{
${ }^{3}$ O Novo Código de Processo Civil, reservou espaço, em sua Exposição de Motivos, para tratar da estabilidade da jurisprudência: "[...] haver, indefinidamente, posicionamentos diferentes e incompativeis, nos Tribunais, a respeito da mesma norma jurídica, leva a que jurisdicionados que estejam em situações idênticas, tenham de submeter-se a regras de conduta diferentes, ditadas por decisões judiciais emanadas de tribunais diversos. Esse fenômeno fragmenta o sistema, gera intranquilidade e, por vezes, verdadeira perplexidade na sociedade. (...) A segurança jurídica fica comprometida com a brusca e integral alteração do entendimento dos tribunais sobre questões de direto.

Encampou-se, por isso, expressamente princípio no sentido de que, uma vez firmada jurisprudência em certo sentido, esta deve, como norma, ser mantida, salvo de houver relevantes razões recomendando sua alteração. Trata-se, na verdade, de um outro viés do princípio da segurança jurídica, que recomendaria que a jurisprudência, uma vez pacificada ou sumulada, tendesse a ser mais estável.

(...)

O novo Código prestigia o princípio da segurança jurídica, obviamente de indole constitucional, pois se hospeda nas dobras do Estado Democrático de Direito e visa a proteger e a preservar as justas expectativas Cadernos do Programa de Pós-Graduação em Direito PPGDir./UFRGS | Edição Digital | Porto Alegre | Volume XI | Número 1 | 2016 | P. 247-267
} 


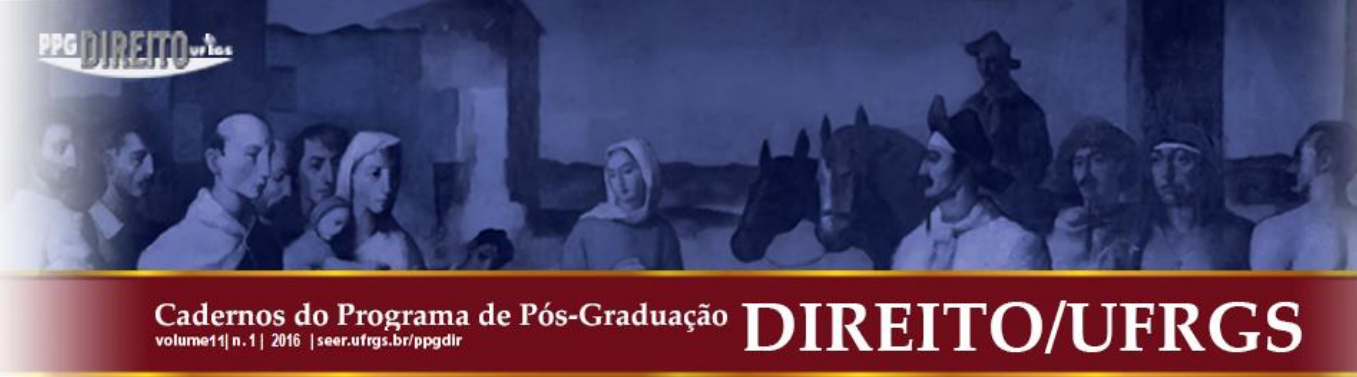

Por questões didáticas e por evidente extensão dos temas acima relacionados, não iremos abordar cada um daqueles institutos, nos atendo a cuidar da nítida tendência de consagração da força da jurisprudência, assim como das dificuldades que tal método de aplicação do direito tem enfrentado no cenário judiciário brasileiro.

A avalanche de reformas no sistema processual pátrio, havida principalmente após a edição da Emenda Constitucional n ${ }^{\circ}$ 45/04, vem demonstrando inegável fortalecimento da jurisprudência, seja através dos julgamentos reiterados, seja por meio das súmulas de caráter vinculante ou meramente persuasivas, estreitando os laços de nossa cultura jurídica da civil law com aquela do judge make law. Vivemos um momento em nosso processo civil em que o modelo codificado da civil law está se reinventando para fortalecer o modelo de precedente ou o direito jurisprudencial típico do common law.

Tal concepção faz com que tenhamos um common law à moda da casa, o que, a princípio, não necessariamente é negativo, contudo, mazelas tem acometido a efetividade desse novo modelo, distorcendo o processo de formação dos precedentes e a aplicação das súmulas (diga-se an passant, cada dia mais entronadas como rainhas na solução das demandas judiciais, servindo, até mesmo, como fundamentação de decisões sem maiores preocupações a respeito do processo de aplicação).

A inserção forçada dos precedentes em nosso cotidiano judiciário, com aplicação indiscriminada de verbetes através de mecanismos singelos de subsunção lógico-formal, sem qualquer evolução gradual ou amadurecimento do sistema, tem feito com que tenhamos, mais uma vez, a utilização de uma salutar ferramenta com olhos meramente casuísticos, com vistas à busca de uma solução imediatista de redução do número de processos e recursos nas Cortes do país (a propósito, cada dia mais salta aos olhos a tendência de formação de uma jurisprudência defensiva voltada a dificultar a análise do mérito dos recursos, notadamente, o especial e o extraordinário).

Esse common law abrasileirado tem sido apresentado como o apanágio da celeridade e da segurança jurídica, mas, a bem da verdade, se presta como mero desafogador de feitos, simples facilitador de julgamentos e impedimentos de admissão dos recursos, com simplista aplicação de enunciados, de forma genérica e abstrata, muitas vezes sem qualquer comprometimento com fatos e teses que originaram o verbete, ensejando em sérios riscos na 
prestação da tutela jurisdicional e perniciosa distorção de relevantes institutos que poderiam, efetivamente, melhorar a prestação jurisdicional.

Não raras as oportunidades em que nos deparamos com a total desconsideração da ratio decidendi (motivos determinantes do caso concreto para formação do precedente) pelo órgão julgador que aplica a súmula ou jurisprudência, desprezando a adequada extração desses motivos para comparação com o caso concreto que lhe fora posto à apreciação, sobressaindo o distanciamento de enunciados genéricos e abstratos (que pretendem exaurir todo necessário para aplicação dos precedentes) e o fato concreto. Tem-se visto os verbetes como manifestação máxima da jurisprudência, o que é um engodo, posto que os precedentes não se resumem a súmulas.

Clarividente está a tentação de nossos julgadores na aplicação indistinta de súmulas e na uniformização superficial das teses jurídicas, sem qualquer amadurecimento, quase numa atuação de ineditismo, impedindo a consolidação de diferentes visões e a ampliação dos debates argumentativos que contribuiriam sobremaneira na formação e uma jurisprudência mais sólida e em precedentes mais estáveis e legítimos.

Podemos citar, a título de exemplo, a recente discussão acerca da utilização da TR como índice de correção do saldo do Fundo de Garantia por Tempo de Serviço, a qual, poucos meses após seu surgimento, teve o trâmite das ações suspensas pelo STJ para julgamento pelo rito dos recursos repetitivos, mesmo sabendo que inúmeros casos, sequer tinham apreciação pelos Tribunais Regionais Federais, o que compromete gravemente a formação da orientação jurisprudencial que advirá do julgamento dos paradigmas em tela. $\mathrm{O}$ paradigma trata-se do Recurso Especial 1.381.683, do Estado de Pernambuco, interposto numa ação coletiva movida pelo SINDIPETRO PE/PB em face da CEF, sob relatoria do Ministro Benedito Gonçalves, mas será que toda senda argumentativa aqui se exaure? Será que não teremos prejuízos na argumentação levando em conta a vastidão de nosso território e dos posicionamentos de

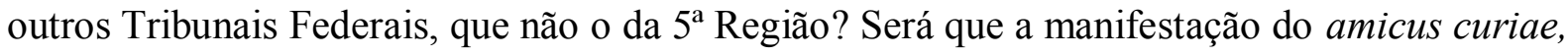
na forma do Art. 543-C, do Código de Processo Civil mostra-se como ferramenta apta a suprir tal oportunidade de ampliação do debate?

Evidente a distorção na aplicação dos precedentes em nosso sistema processual civil, eis que tem-se privilegiado a celeridade, a redução de feitos e de recursos, a qualquer custo, sem comprometimento ou responsabilidade na formação dos julgados que orientarão a aplicação 


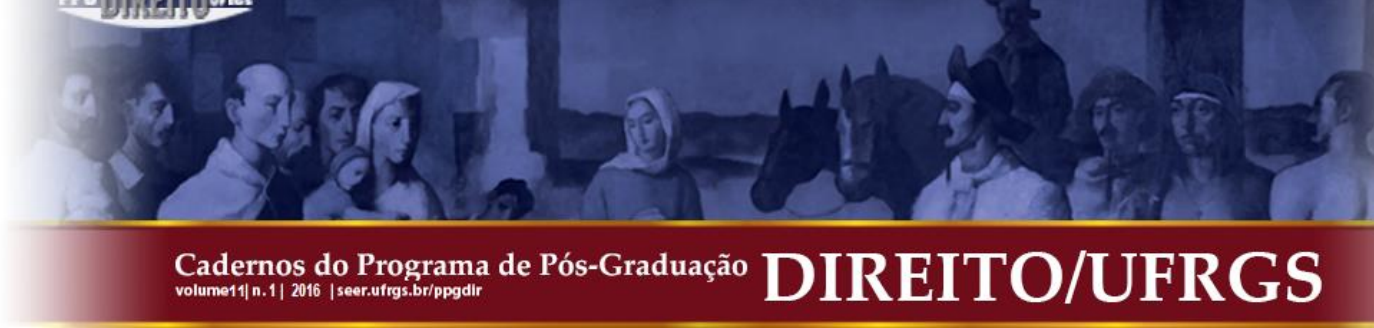

do Direito nas mais diversas searas (por vezes, até mesmo administrativamente, como ocorre nas súmulas vinculantes).

É passada a hora de enaltecermos uma cultura de responsabilidade na formação dos precedentes e do stare decisis (força vinculativa dos precedentes, essa sim voltada à prestigiar a segurança jurídica e a igualdade entre os que buscam a tutela do Estado-juiz), sem que eles sejam minimizados em pequenos verbetes, no mais das vezes, resumidos ao tamanho de uma ou duas linhas.

É preciso impedir que elementos secundários na formação desses precedentes (obter dictum) sejam tratados como motivos determinantes ou sejam aplicados sem qualquer parcimônia ou investigação socioeconômica ou cultural do litígio, causando graves distorções na aplicação do Direito e, ao revés da criação da estabilidade, engessem a evolução gradativa do Direito e solidifiquem a injustiça, desvirtuando um caminho tão importante ao sistema processual.

Afora a aplicação indiscriminada dos julgados, é iniludível o vício na formação desses falaciosos precedentes, com nítida má escolha dos casos paradigmas manejados no julgamento dos recursos repetitivos, correndo-se o risco de que tribunais mais céleres restrinjam o âmbito das teses debatidas e analisadas nas Cortes Superiores, com a suspensão dos casos na origem dos tribunais menos céleres, como alhures exemplificado.

Ainda no tocante às vicissitudes na escolha dos precedentes, podemos citar elucidativamente o Recurso Especial 1.199.715/RJ, sob relatoria do Min. Ari Pargendler que, em partes, estava assim ementado: "1. "Os honorários advocatícios não são devidos à Defensoria Pública quando ela atua contra pessoa jurídica de direto público à qual pertença" (Súmula 421/STJ). 2. Também não são devidos honorários advocatícios à Defensoria Pública quando ela tua contra pessoa jurídica de direto público que integra mesma Fazenda Pública”. Até aqui, nada há que se reprimir, o representativo da controvérsia discutia pagamento de honorários em favor da Defensoria Pública. Contudo, a Defensoria não mais atuava nesse feito desde a primeira instância; como criar um precedente onde o maior interessado no debate não teve oportunidade de argumentação na Corte Superior? Notória a distorção na formação do precedente, a violação da ampla defesa e do contraditório, entretanto, ainda assim, esse é o julgamento que orientará a jurisprudência.

Poder-se-ia aduzir que cuida-se de um caso isolado e que não reflete a realidade e que os paradigmas são criteriosamente escolhidos; não é o que ocorre e, para tanto, citamos outro 


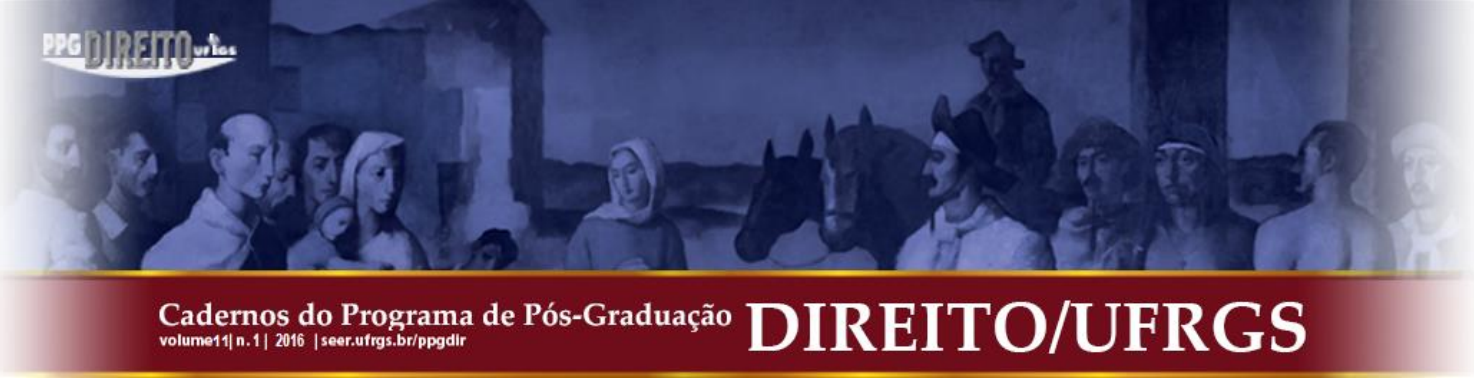

exemplo, o Recurso Especial 911.802/RS, relatado pelo Ministro José Delgado, que cuidava da exigência de pagamento da assinatura básica de telefonia pelos usuários ${ }^{4}$.

Nesse caso houve o reconhecimento da admissão da cobrança da referida taxa básica pelas empresas de telefonia que operam no território nacional, o que envolve milhões de usuários. O caso julgado, entretanto, segundo informações extraídas do sítio do próprio Superior Tribunal de Justiça, trata-se de um caso movido em causa própria, sob a égide da assistência judiciária gratuita, por consumidora evidentemente vulnerável (sob todos os aspectos) em face do poder de que são detentoras tais empresas concessionárias do serviço público em comento.

No recurso em tela, por evidente, restou alijada a paridade das partes, ainda assim, o precedente se solidificou-se e acabou por pacificar a matéria, o que escancara a necessidade de revisitarmos as ferramentas de formação dos precedentes em nosso sistema processual e de fortalecermos os métodos de observância do stare decisis, para que não se deturpe a concepção de obediência da jurisprudência.

Imprescindível se mostra que atuemos na maturação das técnicas de formação e operação dos precedentes judiciais a serem manejados como forma de uniformização das decisões, de tal sorte a impedir distorções na aplicação da cultura do common law em nosso sistema, em nome do proveito de resultados imediatistas de diminuição no número de feitos em trâmite ou de recursos que pendem de julgamento nos tribunais pátrios.

Caso assim não procedamos, temos fundado receio de que, ao invés de reduzir a litigiosidade, vamos viver - se é que já não estamos vivendo - um ambiente institucional com, ainda menor, sensação de ausência de paz social, contrariando o esperado pela Constituição Federal, assentando-se como cenário pernicioso à credibilidade do Órgão Jurisdicional, ao fortalecimento do processo de construção democrática, à consolidação das estruturas fundantes do Estado de Direito e aos fundamentos e objetivos da República.

Pertinente, nessa esteira, suscitarmos os ensinamentos de Boaventura de Souza Santos (2013, p. 208-222):

\footnotetext{
${ }^{4}$ TRIBUNAL DE JUSTIÇA DO ESTADO DO RIO GRANDE DO SUL. Recurso Especial 911.802. Processual Civil. Recurso Especial representativo de controvérsia. Art. 543-C, do CPC. Administrativo. Serviço de telefonia. Demanda entre concessionária e usuário. PIS e COFINS. Repercussão jurídica do ônus financeiro aos usuários. Faturas telefônicas. Legalidade. Disposição na Lei no 8.987/95. Política tarifária. Lei 9.472/97. Tarifas dos serviços de telecomunicações. Ausência de ofensa a normas e princípios do Código de Defesa do Consumidor.
} 


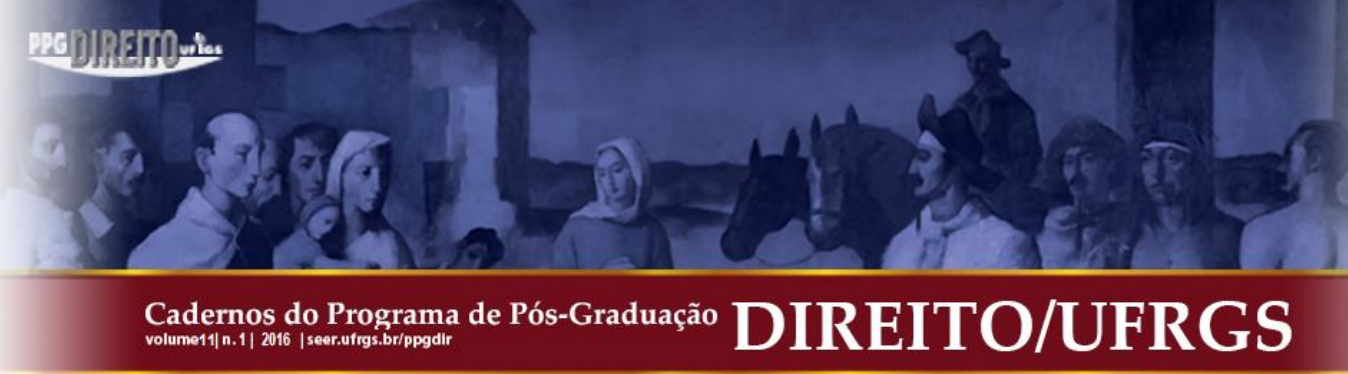

nosso trabalho e nossa organização têm condições de produzir os frutos que se farão
presentes. Será inútil, portanto, e frustrante, pretendermos que o Direito seja nosso
Papai Noel e com suas formulações (palavras, palavras e palavras!) coloque em
nossos sapatos os presentes que não pudemos adquirir com nossa luta política.
[...]
Não se afirma que o pensado ontem é hoje de nenhuma valia. Seria estultice afirmar
isso. O que se diz é que devemos partir dos ganhos que usufruímos dos que ontem
pensaram o homem e sua história e, alicerçados nessa base sólida vermos adiante,
para enxergar o nosso tempo. [...] Para o homem não há caminhos feitos. É
caminhando que fazemos os caminhos.

Pois bem, a tendência de aproximação entre nosso tradicional e usual civil law com a família anglo-saxã do common law é inegável e irrevogável, o que, por si só não é negativo, do contrário, acreditamos seja bastante válido, restando, agora, amadurecermos no manejo peculiar desse sistema, não o reduzindo meros enunciados ou verbetes, mas sim, nos preparando desde os bancos da faculdade de Direito até no recrutamento/formação dos magistrados, como forma de alcançarmos uma tutela jurisdicional mais efetiva, equânime e segura, que corrobore com os primados constitucionais e substancialmente contribua na construção de uma sociedade mais justa, livre, isonômica e fraternal.

\section{CONCLUSÃO}

Podemos denotar que o processo civil brasileiro sempre fora objeto de abordagem constitucional e, no atual modelo, tem ocupado espaço de destaque, até porque, não se pode negar, que através do processo se tem parcela importante na construção democrática do Estado.

Neste diapasão, a fim de que o processo civil seja exitoso na consecução de tal papel, imprescindível se faz refletir acerca de uma nova perspectiva na prestação dessa tutela estatal, especialmente, para assegurar um mínimo de previsibilidade e segurança jurídica, implicando na necessidade de construção de ferramentas que prestigiem os precedentes judiciais, isso tudo, por evidente, sem macular o livre convencimento do magistrado. A bem da verdade, precisamos descontruir esse paradigma que tem gerado situações de absoluta desigualdade e incerteza jurídica, o que macula a credibilidade do Órgão Judiciário.

Tal transformação na forma de se prestar tutela jurisdicional tem gerado uma aproximação do processo civil pátrio com a família jurídica, de tradição anglo-saxã, do common law, de tal sorte que tem-se valorizado instrumentos processuais que fortalecem os precedentes. 


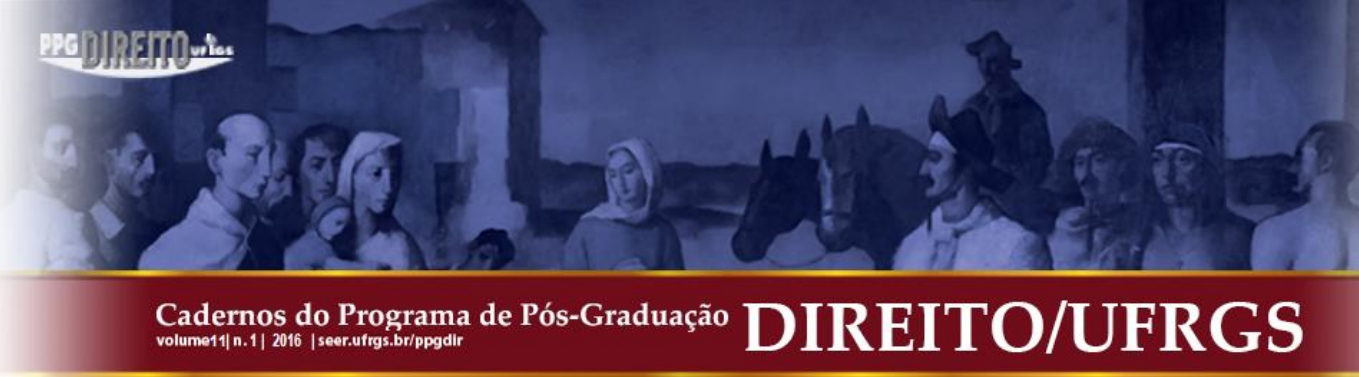

A postura, entretanto, que poderia ser digna de aplausos, a bem da verdade, tem gerado um common law à moda da casa, onde os precedentes tem se resumido a meros verbetes e súmulas, sem qualquer consideração da ratio decidendi, aplicação indiscriminada das decisões e, pior, por vezes até com decisões paradigmáticas alheias dos demais casos que lhe acompanharão, proporcionando uma severa distorção do fenômeno processual, de tal maneira que devemos repensar nosso modelo de aplicação do sistema dos precedentes para gozar, em plenitude, dos resultados que tal mecanismo pode nos proporcionar.

\section{REFERÊNCIAS}

CAPPELLETTI, Mauro. Acesso à justiça. Porto Alegre: Sérgio Antônio Fabris Editor, 2008.

. Il processo come fenomeno sociale di massa. Giustiza e Società. Milano: Edizioni di Comunità, 1977.

CHIOVENDA, Giuseppe. Instituições de Direito Processual Civil. 4. ed.. Campinas: Bookseller, 2009.

DAVID, Rene. Os grandes sistemas do direito contemporâneo. São Paulo: Martins Fontes, 2002.

DINAMARCO, Cândido Rangel. A instrumentalidade do processo. 12. ed. São Paulo: Malheiros, 2005.

; GRINOVER, Ada Pellegrini; CINTRA, Antônio Carlos de Araujo. Teoria Geral do Processo. 18. ed. Malheiros, São Paulo, 2002.

MACEDO, Elaine Harzheim; STAFFEN, Márcio Ricardo (org.). Jurisdição e processo: tributo ao constitucionalismo. Belo Horizonte: Arraes Editores, 2012.

MANCUSO, Rodolfo de Camargo. A resolução dos conflitos e a função judicial no contemporâneo Estado de Direito. São Paulo: Revista dos Tribunais, 2010. 


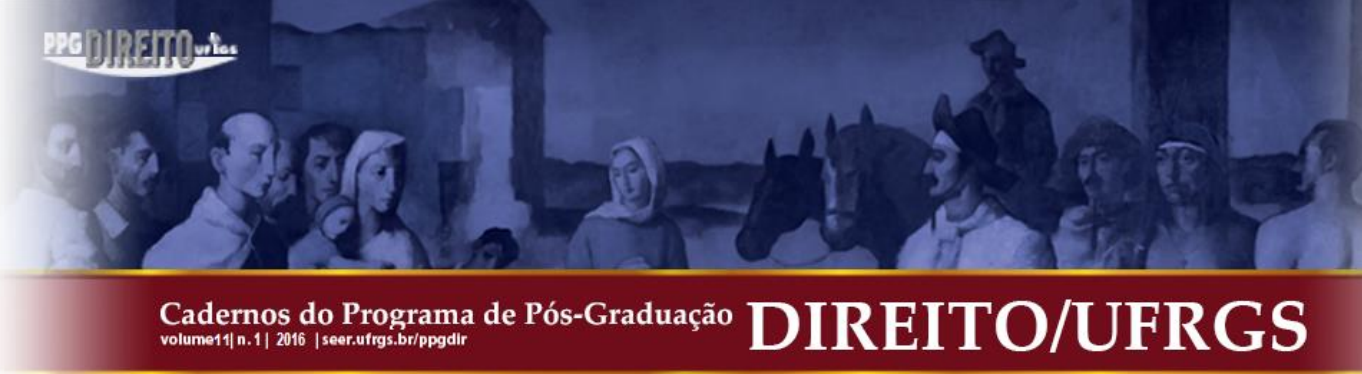

MARINONI, Luiz Guilherme. A força dos precedentes. 2. ed. Salvador: Jus Podium, 2012. . Precedentes obrigatórios. São Paulo: Revista dos Tribunais, 2010.

MATOS, José Igreja. Um modelo de juiz para o processo civil actual. Coimbra: Coimbra Editora, 2010.

MELlO, Celso Antônio Bandeira de. Curso de direito administrativo. 13. ed. São Paulo: Malheiros, 2001.

NOGUEIRA, Gustavo Santana. Precedentes vinculantes no direito comparado e brasileiro. 2. ed. Salvador: Jus Podium, 2013.

OLIVEIRA, Carlos Alberto Alvaro de. Do formalismo no processo civil. 3. ed. São Paulo: Saraiva, 2009.

PASSOS, J.J. Calmon de Passos. Revisitando o direito, o poder, a justiça e o processo. Salvador: Jus Podium, 2012.

ROSAS, Roberto; ARAGÃO, Paulo Cezar. Comentários ao Código de Processo Civil. 2. ed., v. 5. São Paulo: Revista dos Tribunais, 1998.

SANTOS, Boaventura de Sousa. Pela mão de Alice: o social e o político na pósmodernidade. 14. ed. São Paulo: Cortez, 2013.

SILVA, Ovídio Araújo Baptista da. Processo e ideologia: o paradigma racionalista. 2. ed. Rio de Janeiro: Forense, 2006.

SOUZA, Marcelo Alves Dias de. Do precedente judicial à súmula vinculante. Curitiba: Juruá, 2013.

TUCCI, José Rogério Cruz e. Tempo e processo: uma análise empírica das repercussões do tempo na fenomenologia processual (civil e penal). São Paulo: Revista dos Tribunais, 1997. 


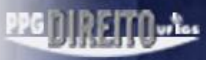

Cadernos do Programa de Pós-Graduação volume11|n.1| 2016 | seer.ufrgs.br/ppgditr

Garantias constitucionais da duração razoável e da economia processual no Projeto do Código de Processo Civil. Revista de Processo - REPRO. n. 192, São Paulo, fev. 2011, p. 193-208.

Submissão: $11 / 01 / 2016$

Aceito para Publicação: 17/03/2016 


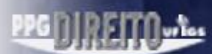

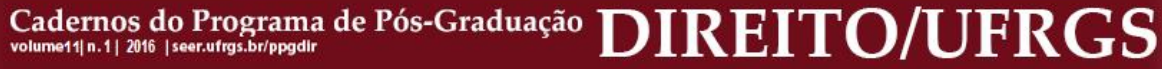

